\title{
Extinction of Lasiommata petropolitana (Fabricius, 1787) (Lepidoptera: Nymphalidae) in the Czech Republic: a case of habitat loss at a range margin
}

\author{
Lukáš Spitzer, Jiří Beneš \& Martin Konvička
}

\begin{abstract}
Extinction of Lasiommata petropolitana (Fabricius, 1787) (Lepidoptera: Nymphalidae) in the Czech Republic: a case of habitat loss at a range margin - Acta Mus. Siles. Sci. Natur., 66: 271-279, 2017.

Abstract: Lasiommata petropolitana is a boreomontane butterfly, declining in Central Europe and not recorded in the Czech Republic since 1975. Based on revision of all existing archival records and results of recent targeted surveys in mountainous regions of East Moravia, area of its past occurrence, we document its gradual retreat and ultimate regional extinction. The historical range, marginal with respect to contiguous distribution along the Carpathian mountain chain, included both foothills and higher elevations of Bílé Karpaty, Hostýnské Vrchy, Javorníky, Moravskoslezské Beskydy and Vsetínské Vrchy Mts; pre-1950 records document also a past occurrence at calcareous bedrock localities in Brno environs. Other past lowland records (Oslava valley, Olomouc, Znojmo) were due to misidentifications. Within the historical Czech range, the butterfly inhabited pastures with exposed calcareous, flysh or sandstone bedrock, maintained by traditional grazing. The decline of the species proceeded from lower elevations and foothills towards mountain ridges. The higher elevation sites were encroached by successional changes, or intentionally afforested, with post-war decline of mountain grazing. This development went largely unnoticed by conservation authorities, and represents a loss of mountain butterfly from marginal parts of its range.
\end{abstract}

Key words: butterfly, extinction, Moravia, mountain habitats, Northern Wall Brown, Satyrinae, western Carpathians.

\section{Introduction}

The Northern Wall Brown (Lasiommata petropolitana, Fabricius 1787) is one of butterflies recently declining in Europe. It is recorded from 27 European countries (Kudrna et al. 2011), the situation in individual countries is either stable, or declining in terms of abundance or distribution and seems to be worse in lowlands than in mountains (van Swaay \& Warren 1999). In Germany and Poland, the species is listed as endangered (Pretscher 1998; Buszko \& Nowatzki 2002). In the Czech Republic the species was listed as endangered too (Farkač et al. 2005), but in new edition of Red list is mentioned as extinct (Hejda et al. 2017). The inhabited area is $19.95 \%$ across Europe and western Russia (371 BRF, basic recording fields, cf. Kudrna et al. 2011).

The species inhabits a discontinuous Eurosiberian range, which includes higher mountains of temperate Europe, (Pyrenees, Alps, Apennines, Carpathians and mountain ranges at Balkan peninsula), plus bogs and wetlands in low to middle altitudes of north-eastern Europe, from eastern Poland to Fennoscandia and Russia. Beyond Europe, the range stretches through Siberia to north-eastern China and Russian Far East (Beneš et al. 2002). In a past, L. petropolitana locally occurred also in lower altitudes of Central Europe, usually in climatically mesoclimatically cool conditions of river canyons with steep, sparsely vegetated slopes (Reichl 1992).

The butterfly is a mesophilous species using common grasses as larval hosts. The flight period is in May-June. The mountain populations are univoltine, but a second brood can be experimentally induced in captivity (Nylin et al. 1996; Gotthard 1998). In European mountains, the butterfly inhabits woodland clearings and meadows, opening along forest roads and other open patches with grassy vegetation, usually from $600 \mathrm{~m}$ a.s.l. up to the timberline. The old 
records from lowlands suggest an occurrence in warmer forest-steppes on calcareous rocky terrains (mainly in eastern Austria and South Moravia, SE Czech Republic) (Povolný \& Gregor 1946).

Compared to the first half of the 20th century, the Central European distribution has diminished considerably, in particular in lower altitudes. There are only few post-1960 low altitudes records from Austria (Reichl 1992) and the Czech Republic (Povolný \& Gregor 1946; Beneš et al. 2002), but the butterfly is still common in the Alps. In Poland, the lowland population in eastern part of the country (Puszcza Bialowieska Forest), probably belonging to the contiguous eastern distribution, are most likely extinct (Sielezniew \& Dziekańska 2010). Mountain Polish populations exist in three Carpathian ranges bordering with Slovakia (Tatra Mts, Pieniny Mts, Beskyd Sadecki Mts), but the species is reportedly not common there (Buszko \& Nowacki 2000). In contrast, the species is still in good conditions in higher mountains of Slovakia (Reiprich 1960; Hrubý 1964; Reiprich \& Okáli 1989; Kudrna et al. 2011; L. Vít'az pers. comm.), but has reportedly declined in the lower ranges bordering Slovakia/Czech Republic borders. From the latter area, there exist older and currently unconfirmed records from the Kysucké Beskydy Mts (Source: coll. Slezské zemské muzeum v Opavě), and a currently recorded population around the Vršatecké Bradlo Hill (L. Vít'az pers. comm.) in Slovakia.

To elucidate details of L. petropolitana distribution changes in the Czech Republic during the last century, this paper reviews existing archival sources (literature, and both public and private collections) and confronts them with current results of butterfly distribution mapping, targeted surveys of the last existing localities and evaluating their current state. The authors have first-hand knowledge of most of the historical localities, particularly so in the Beskydy and Bílé Karpaty Mts in the Czech Republic / Slovakia borderlands. Confronting the past records with current knowledge allowed us to clarify the species' status in the Czech Republic and discuss the reasons of its loss from the country.

\section{Material and methods}

Besides of reviewing published literature, we revised material in 52 public collections in the Czech Republic, including the largest one in the National Museum, Prague, and consulted numerous recorders who have worked in the mountainous Czech / Slovak borderland.

For the current situation, we worked with the Czech Republic Butterflies and Moths Recording database administered by Biology Centre, Czech Academy of Sciences, České Budějovice, supplemented by Species Occurrence Database, administered by Nature Conservation Agency of the Czech Republic, Prague (both databases include approximately 2 million localised records to date). For the area of interest, five targeted recording projects (with records also included to the former database) considerably increased the recent knowledge: two targeted Bílé Karpaty Mts (Horal et al. 2006; Uřičář et al. 2016), two Beskydy Mts (Pitro \& Wolfová 2008; Spitzer 2008), one Moravský Kras Protected Landscape Area (Laštůvka \& Marek 2002) and one Podyjí National Park (Šumpich 2007).

\section{Results}

\section{Archival records}

The following list, organised according to individual regions or mountain ranges, combines published and collection records. There is mentioned number of faunistic grid in brackets to each locality.

\section{Brno environs}

Moravia mer., Adamov-Vyškůvka (6665), 465 m a.s.1., 28.vii.1931, 1 spec., Cedivoda leg., O. Jakeš rev., coll. Moravské zemské muzeum v Brně, Brno; Moravia mer., Brno (Bergwalden) (6765), before 1912, v.-vi. and viii. Kupido leg. (Skala 1912); Moravia mer., Kuřim-Čebínka (6664), 30.viii.1942, 1 spec. (Povolný et Gregor 1946). 


\section{Carpathians}

Bílé Karpaty Mts

Moravia or., Nedašov (6874), v.1972, 1 ex., Z. Laštůvka leg.

Hostýnské vrchy Mts

Moravia or., Hulín environs (6671), 5.vi.1965, 1 ô, Drulák leg., J. Beneš and L. Spitzer rev., coll. Muzeum Kroměřížska, Kroměříž.

\section{Vsetinské vrchy Mts and Javorniky Mts}

Moravia or., Zděchov (6774), 8.vi.1962, 1 đ̄, J. Starý leg., J. Beneš rev., coll. Muzeum regionu Valašsko, Vsetín

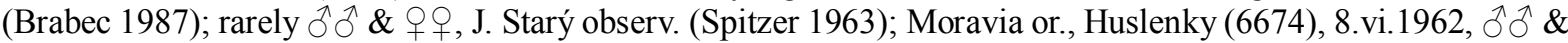
우, J. Starý observ. (Spitzer 1963); Moravia or., Valašská Bystřice-Vsacká Tanečnice (6675), $1 \mathrm{~km}$ beneath the summit, approach from Rožnov pod Radhoštěm, about 900 m a.s.l., 15.v.1959, abundant §ิð̄, K. Spitzer observ. (Spitzer 1963); Moravia or., Velké Karlovice-Solán̆ (6676), 15.v.1959, 1 đ̊, K. Spitzer observ. (Spitzer 1963), 31.v.-6.vi.1973, 12 spec. O. Jakeš leg. et coll., dosents spec., O. Jakeš observ.; Moravia or., Francova LhotaPulčínské skály (6774), 600 m a.s.1., 21.v.1952, 1 ô, E. Fiala leg., coll. L. Fiala, L. Spitzer rev.; Moravia or.,

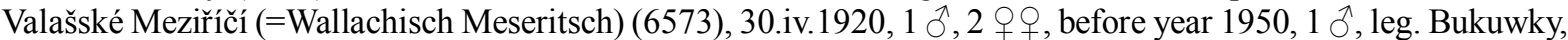
J. Beneš rev., coll. Slezské muzeum v Opavě; Moravia or., Horní Bečva (6575), between 1929-1936, 1 spec., R. Dernický leg. (Dernický 1945); between 1963-1972, v.1972, 17 spec., J. Černý leg. (Černý 1972), 9.v.1972, 3 ex., 15.v.1971, 1 đ̃, 1 q, J. Černý leg., L. Spitzer rev., coll. Muzeum Novojičínska, Muzeum v Příboře, 18.v.1971, 2 đ̂̃ , J. Kozel leg., L. Spitzer rev., coll. Muzeum Novojičínska, Muzeum v Příboře (Stiova 1975).

\section{Moravskoslezské Beskydy Mts}

Moravia bor., Beskydy, Lysá hora (6476), v.1933, 5 đ̂̃ , Burčík leg., J. Beneš rev., coll. Ostravské muzeum v

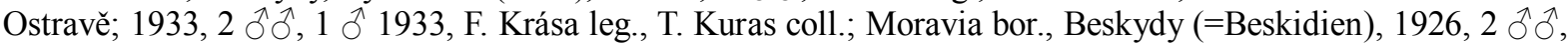
Pekarský leg., J. Beneš rev., coll. Ostravské muzeum v Ostravě; Moravia bor., Beskydy, Frýdlant nad Ostravicí (=Beskieden, umg. Friedland) (6476), 800 m a.s.l., 1935, 1 §̃, Biener leg., J. Beneš rev., coll. Slezské muzeum v Opavě; Moravia bor., Beskydy (=Beskieden), Lomná (6478), 20.vi.1932, 1 đ̃, Biener leg., J. Beneš rev., coll. Slezské muzeum v Opavě; Moravia bor., Morávka, 23.v.1948, F. Dias lgt. et coll.; Moravia bor., Morávka-Uspolka

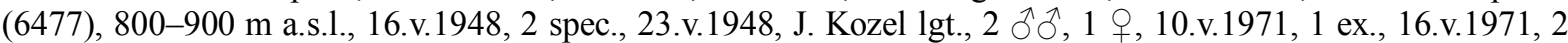

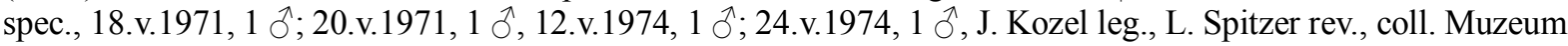
Novojičínska, Muzeum v Příboře; Moravia bor., Bílá-Konečná (6577), about 700 m a.s.l., 18.v.1975, 1 đ̃, leg. et coll. L. Fiala, L. Spitzer rev.; Moravia bor., Horní Bečva, near the summit Kladnatá, alt. 700-800 m, v.1967, 17 spec., J. Černý leg. et coll. (Černý 1972); Moravia bor., Horní Bečva-Pustevny (6575), 1100 m a.s.l., 6.vi.1973, 1 spec. leg. et coll. Jakeš, 4 spec., O. Jakeš observ.; Moravia bor., Krásná-Visalaje (6477), before year 1950 (Králíček \& Povolný 1980), vi.1973, a few spec., O. Jakeš observ.; Moravia bor., Krásná-Bílý Kř́ž (6477), before year 1950 (Králíček \& Povolný 1980); Moravia bor., Krásná-Bílý Kř́íž, Sulov (6477 and 6577) 6.vi.1973, 1 ex. leg. et coll. O. Jakeš.

\section{Non-accepted records}

The following records, all without voucher specimen, likely originated due to confusion with Lasiommata maera (Linnaeus, 1758):

Ketkovice, Ketkovický Mlýn, Oslava valley (6863), before 1912, 1 spec., Kř́ž leg. (Skala 1912); Olomouc (6369), before 1912, 1 spec., Kaspar leg. (Skala 1912) (the record is not mentioned in a later summary publication by the collector, i.e. Kaspar /1938/, and voucher specimen is not deposited in the collection of Kaspar in the Olomouc Museum); Znojmo (7162), before 1912, 1 spec. in viii, Kupido leg. (Skala 1912; Švestka \& Vítek 1988).

\section{Current situation}

After 2002, there was intensive recording effort in the region historically inhabited by L. petropolitana, including several targeted surveys and heightened emphasis on rediscovering the butterfly. Intensity of the effort is apparent by comparing the total numbers of post-2002 butterfly records from the historically occupied grid squares $(\mathrm{N}=20$; mean number of records $=2090.8, \mathrm{SD}=2477.0$, range $=127-11001)$ with numbers of records originating from the remaining Czech Republic grid squares $(\mathrm{N}=655$; mean $=657.2, \mathrm{SD}=1209.59$, range $=8-12$ 477). The former L. petropolitana range is thus considerably better surveyed, but no recent positive record exists. 


\section{Discussion}

Revision of the Czech Republic public and private collections, combined with results of current butterfly distribution surveys, revealed that voucher specimen of L. petropolitana originating from the country exist in five museums only (none in National museum, Prague), that all material originated from Moravia (the eastern part of the country) and that the last records originated from the 1970s.

Local extinctions from lower elevations, where L. petropolitana formed two generations per year, pre-dated those in mountainous regions. The localities of older records (i.e., Brno, Kurrim) have been well covered by recorders since the late 19th century until present (Skala 1912, 1936; Povolný \& Gregor 1946; Beneš et al. 2002). From the current state of the localities, it appears that the habitats were sparse woodlands or scrub situated on calcareous bedrock. Although much impoverished compared to the situation a century ago, these two localities host xerothermofilous Lepidoptera until present. However, given the L. petropolitana affinity towards colder regions, it is conceivable that the butterfly inhabited cooler, relatively shady sites there, thus partitioning the habitats with warm-requiring butterflies. Large-scale land use changes during the $20^{\text {th }}$ century included cessation of grazing and massive afforestation. Arguably, these changes proceeded faster in cooler mesoclimates, thus bringing about extirpation of L. petropolitana even at sites where more xerophilous butterflies are still surviving.

All records from mid-20th century onwards originated from mountainous outer foothills of the Western Carpathians, regions the Czech/Slovakian borders. Starting from South, i.e. the Bílé Karpaty Mts (maximum altitude $970 \mathrm{~m}$ ), the 1972 record by Laštůvka (faunistic grid 6874 ) is from mountain ridge pastures near Nedašov village (cca $750 \mathrm{~m}$ a.s.1.). These pastures directly adjoin the Vršatecké Bradlo reserve (western Slovakia), a calcareous cliff still inhabited by a vital (univoltine) population of the species (L. Vit'az pers. comm). Beyond the Vršatecké Bradlo population in Slovakia, L. petropolitana vanished from Malé Karpaty Mts and Povážský Inovec Mts, whereas a contiguous distribution begins from Strážovské Vrchy Mts and stretches towards the higher elevated mountain ranges in the North and East (source: www.lepidoptera.sk).

Returning to the Czech Republic territory, L. petropolitana was regularly recorded from Vsetínské and Javorníky Mts (maximum altitude $1024 \mathrm{~m}$ ) until the 1970s, both from the foothills and higher altitudes (Spitzer 1963). Černý (1972) described regular occurrence between 1963 and 1967 near Horní Bečva village, while other records document the butterfly there until 1972 (Stiova 1975). No later evidence exists from these two mountain ranges (cf. Pavelka \& Trezner 2001).

In Moravskoslezské Beskydy Mts (maximum altitude $1323 \mathrm{~m}$ ), occurrence in altitudes 800-1000 m a. s. 1. is documented until 1975 (the last record was near Bílá village); a few isolated records originated from lower altitudes $(500-600 \mathrm{~m})$. As this territory is exceptionally well recorded (e.g., Brabec 1987; Beneš et al. 2002; Pitro \& Wolfová 2008), recent occurrence can be safely excluded.

Regarding habitats in the Bílé Karpaty, Vsetínské Vrchy, Javorníky and Moravskoslezské Beskydy Mts, both locations of the records and published information agree that the butterfly occurred at mountain pastures with barren soils and rocky outcrops, near stony embankments, at small-scaled grassy glades and along forest roads with grassland margins at calcareous (Bílé Karpaty), sandstone or flysch bedrocks. Some authors (e.g., Černý 1972) mentioned a presence of shrubs or small trees. Half-shaded rocky grasslands are until present inhabited by L. petropolitana in Slovakia. In the Czech Republic, where the Carpathian ridge does not approach the timberline, such habitats have been rather scarce. They existed on mountain pastures, maintained by sheep and cow grazing. The local grazing economy had been declining already in early 20th century and the decline has accelerated in the post-war era (Štika 2007). With 
the decline, the pastures on rocky grounds were usually the first to be abandoned, as they were the least suitable for more intensive use. Consequently, the former pastures succumbed to woody regrowth, or to intentionally planted spruce (Tkáčiková \& Spitzer 2011) (Fig. 2).

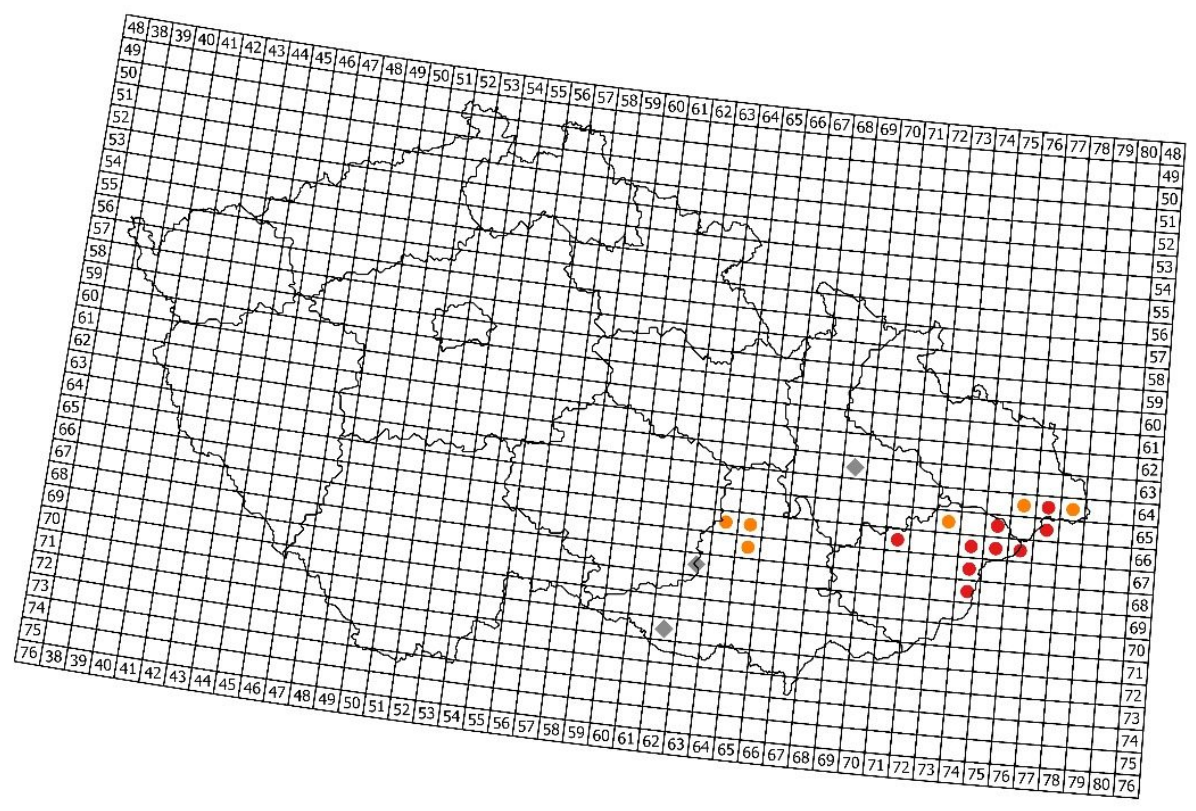

Fig 1: Map of the historical distribution of the Northern Wall Brown (Lasiommata petropolitana) in the Czech Republic. Orange circles: records until 1950, Red circles: records from 1951-1975, Grey rhombus: non-accepted records. Source: Czech Republic Butterflies and Moths Recording.

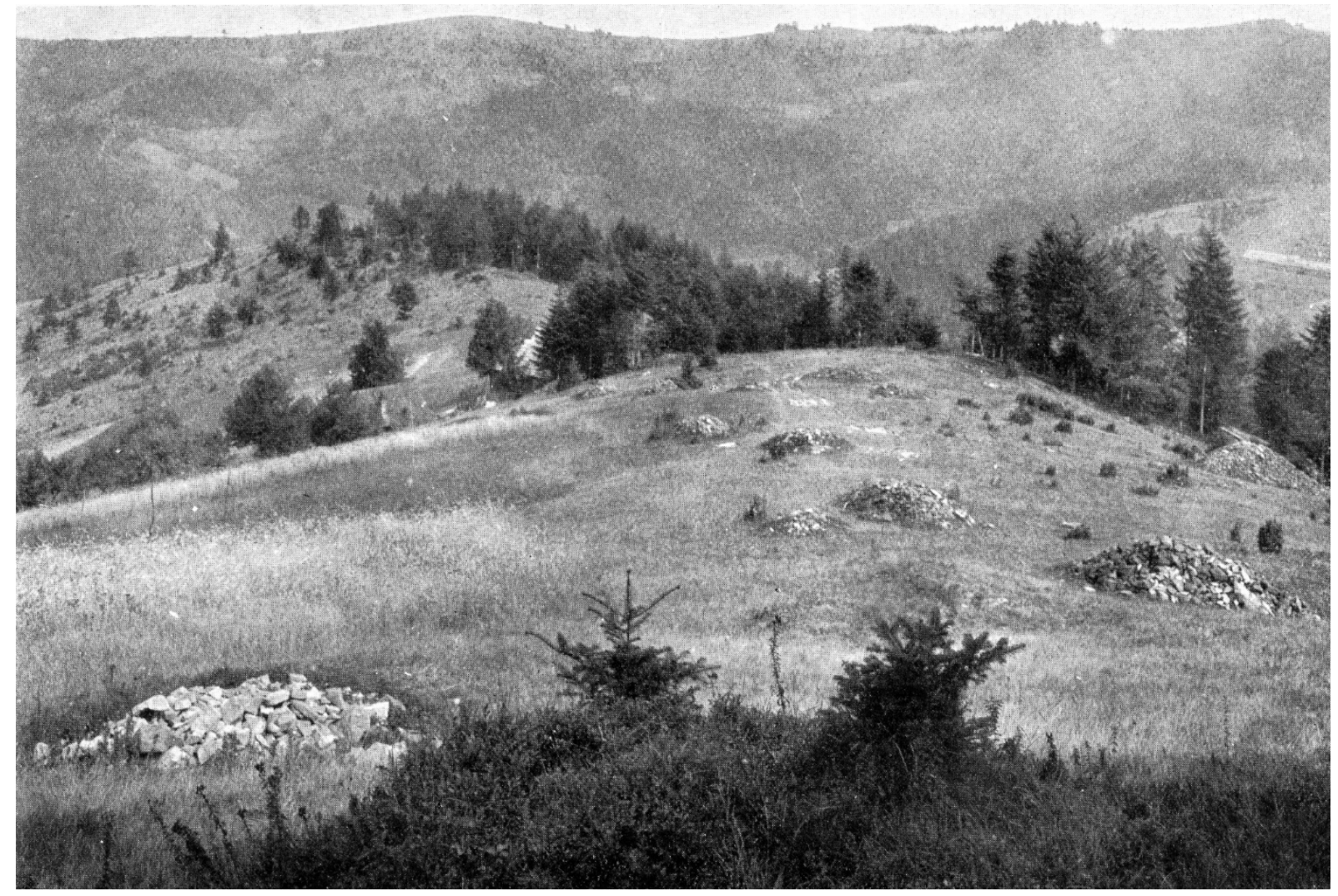

Fig 2: Typical landscape near Velké Karlovice-Soláň in the 1930s. Photo: Archive of Muzeum regionu Valašsko, Vsetín. 

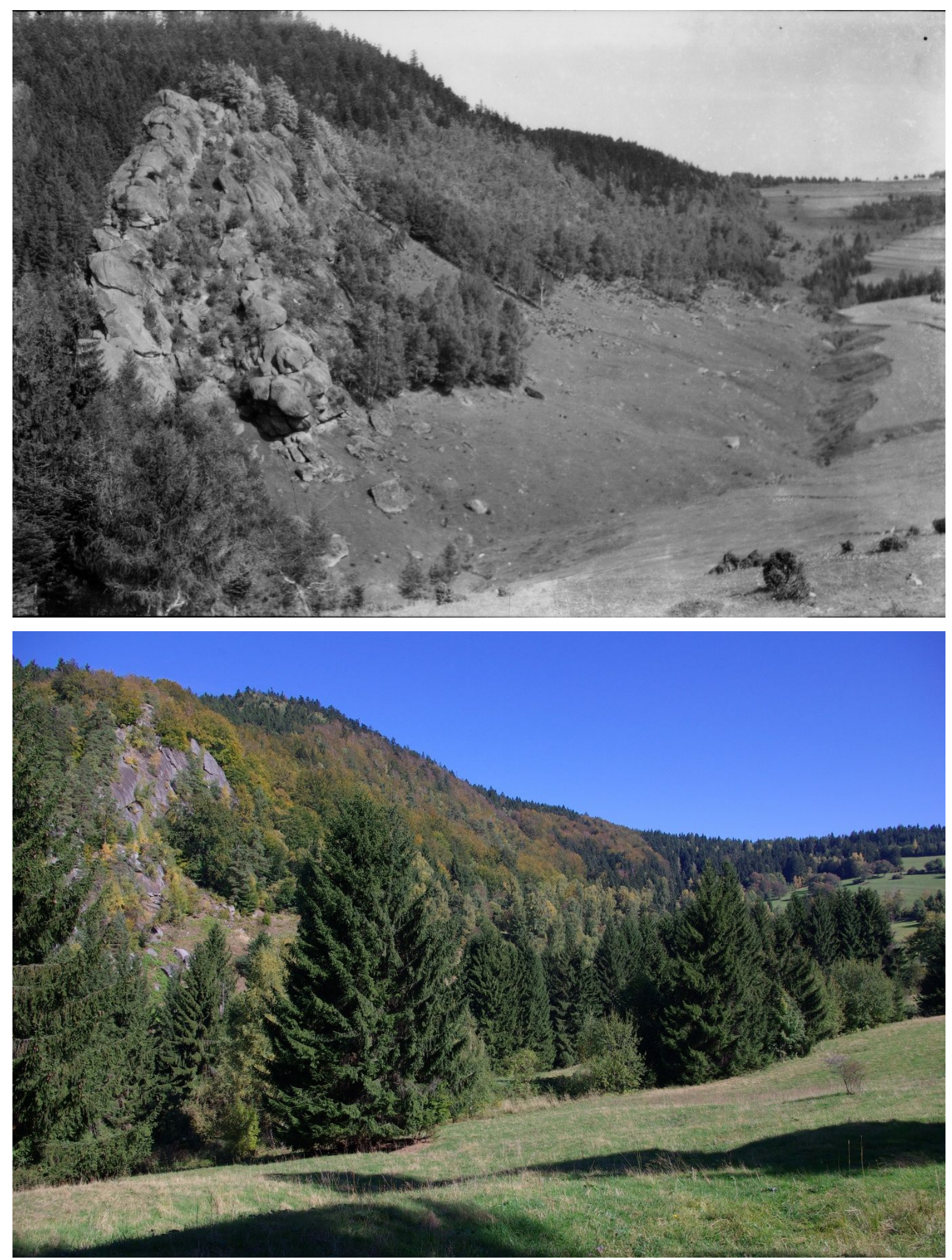

Fig 3: Habitat changes at a classical Lasiommata petropolitana site - Pulčín near Francova Lhota (Vsetín district, eastern Czech Republic) - 1932 (above) and 2012 (below). Photo: Archive of Muzeum regionu Valašsko, Vsetín. 
This development went unnoticed by conservation authorities, despite legal protection of most of the Czech Carpathians landscapes (Beskydy Protected Ladscape Area /PLA/ since 1973, Bílé Karpaty PLA since 1980). The neglect is somehow understandable, as there were more pressing conservation priorities than already fragmented patches of pastures in highest altitudes of the mountains (Jongepierová 2008; Tkáčiková et al. 2013).

In the intermittent period between 1975 (last Czech Republic record) and early 2000s, there were no targeted searches for the butterfly, and it is therefore not possible to pinpoint the precise year of its last occurrence. However, the three post-2000 targeted surverys (Horal et al. 2006; Pitro \& Wolfová 2008; Uřičáŕ et al. 2016) did not return any L. petropolitana records, neither did so our searches near the last known localities (Spitzer 2008). Likewise, a comparison of historical and recent photographs of some of the classical localities (Fig. 2) in fact exclude ongoing persistence of the butterfly in Czech parts of the Carpathian system, as no suitable habitats exist at present.

The loss of $L$. petropolitana from the Czech Republic represents an extinction from a range margin, from region that was naturally suboptimal due to scarcity of rocky substrates. As in other butterflies declining at range margins (e.g., Wilson et al. 2015; Fourcade \& Ockinger 2017), the losses proceeded from isolated populations at the foothills towards higher elevations. In the highest elevations, gradual land use changes, neglected by conservation community, homogenised the formerly diverse landscape towards near-contiguous woodlands, fragmenting the already marginal populations and ultimately causing their extinctions. The species still thrives in Slovakia, but even there, it disappeared from lower-elevated mountain ranges, for reasons most likely identical to those described here. As recent targeted searchers did not yield any new records, 1975 is the year of last L. petropolitana record in the Czech Republic.

Acknowledgements: We are grateful to Henryk Kalivoda and Lubomír Vít'az for valuable information regarding current Lasiommata petropolitana distribution in Slovakia, curators of all the visited musea for access to their collections, and Libor Fiala and Jiří Pavelka for help during field surveys and to Tomáš Kuras for fruitful comments. Funding was provided by Muzeum regionu Valašsko, Vsetín, a Czech Nature Conservation Union (Národni program Ochrana biodiverzity, project n. 01010508) and Grant Agency of the Czech Republic (P505/10/2167, 14-33733S).

\section{References}

Beneš J., Konvička M., Dvořák J., Fric Z., Havelda Z., Pavlíčko A., Vrabec V. \& Wiedenhoffer Z. (eds) (2002): Motýli České republiky: Rozšíření a ochrana I, II. [Butterflies of the Czech Republic: Distribution and Protection I, II.]. SOM, Praha, 857 pp. (in Czech and English).

Brabec L. (1987): Motýli okolí Valašského Meziřičí ve sbírkách Okresního vlastivědného muzea Vsetín. [Butterflies around Valašské Meziříčí in the collections of Regional Museum of Vsetín]. - Zpravodaj Okresního Vlastivědného Muzea ve Vsetíně 1987: 1-14. (in Czech).

Buszko J. \& Nowacki J. (eds) (2000): The Lepidoptera of Poland. A distributional checklist. Polskie towarzystwo entomologiczne, Poznań, Toruń, 178 pp.

- (2002): Lepidoptera. 80-87 pp. In.: Glowaciński Z. (ed.): Red list of threatened animals in Poland. Polish academy of Sciences. Institute of Nature Conservation PAN, Kraków.

Černý J. (1972): Výskyt okáče stínovaného v Beskydech. [Occurrence of the Northern Wall Brown in the Beskydy Mts]. - Entomologický Zpravodaj (Ostrava) 2(1): 8-9. (in Czech).

Dernický R. (1945): Lepidopterologické poznámky z Moravy. - Př́roda 37: 276-285. (in Czech).

Farkač J., Král D. \& Šk orpík M. (eds) (2005): Červený seznam ohrožených druhů České republiky. Bezobratlí. [Red list of threatened species in the Czech Republic. Invertebrates]. Agentura ochrany prírody a krajiny ČR, Praha, 760 pp. (in Czech, English summary).

Fourcade Y. \& Ockinger E. (2017): Host plant density and patch isolation drive occupancy and abundance at a butterfly's northern range margin. - Ecology and evolution 7: 331-345

Gotthard K. (1998): Life history plasticity in the satyrine butterfly Lasiommata petropolitana: investigating an adaptive reaction norm. - Journal of Evolutionary Biology 11(1): 21-39. 
Hejda R., Farkač J. \& Chobot K. (2017): Červený seznam ohrožených druhů České republiky Bezobratlí. (Red List of threatened species of the Czech Republic. Invertebrates). - Prríroda 36: 1-612.

Horal D., Jagoš B., Resl K., Uřičář J., Jongepier J.W. \& Pechanec V. (2006): Atlas rozšíření vybraných druhů živočichů CHKO Bílé Karpaty. [Distribution atlas of selected species of fauna of the White Carpathians]. ZO ČSOP Bílé Karpaty, Veselí nad Moravou, 85 pp. (in Czech).

Hrubý K. (1964): Prodromus Lepidopter Slovenska. [Prodromus Lepidoptera of Slovakia]. SAV, Bratislava, 962 pp. (in Slovak).

Jongepierová I. (ed.) (2008): Louky Bílých Karpat [Grasslands of the White Carpathians Mountains], Veselí nad Moravou, ZO ČSOP Bílé Karpaty.

Kaspar A. (1938) Denní motýli Kosíře. - Časopis Vlastivědného Spolku Muzejního v Olomouci 51: 154-162. (in Czech).

Králíčck M. \& Povolný D. (1980): K súčasnému stavu faunistiky moravských denných motýlov (Lepidoptera, Papilionoidea). [To the current state of Moravian daily butterfly faunistics (Lepidoptera, Papilionoidea)]. Entomologické Problémy 16: 107-131. (in Slovak).

Kudrna O., Harpke A., Lux K., Pennerstorfer J., Schweiger O., Settele J. \& Wiemers M. (2011): Distribution Atlas of Butterflies in Europe. Gesellschaft für Schmetterlingschutz e. V., Halle, 576 pp.

Laštůvka Z \& Marek J. (2002): Motýli (Lepidoptera) Moravského krasu. Diversita, společenstva a ochrana. Korax, Blansko. (in Czech).

Nylin S., Gotthard K. \& Wiklund C. (1996): Reaction norms for age and size at maturity in Lasiommata butterflies: Predictions and tests. - Evolution 50(3): 1351-1358.

Pavelka J. \& Trezner J. (eds) (2001): Př́roda Valašska. [Nature of the Morvian Wallachia region]. ČSOP ZO 76/06 Orchidea, Vsetín, 504 pp. (in Czech).

Pitro Z. \& Wol fová J. (eds) (2008): Zachování biodiverzity karpatských luk. FOA, Nadační fond pro ekologické zemědělství, Praha, 108 pp. (in Czech).

Povolný D. \& Gregor F. (1946): Nálezy několika pro Moravu nových nebo neobvyklých druhů Lepidopter. [Findings of several new or unusual species of Lepidoptera for Moravia]. - Entomologické Listy 9: 68-70. (in Czech).

Pretscher P. (1998): Rote Liste der Großschmetterlinge (Macrolepidotera). Schriftenr Landschaftspfl Naturschutz 55: 87-111.

Reich1 E.R. (1992): Verbreitungsatlas der Tierwelt Österreichs. Band 1: Lepidoptera - Diurna. Tagfalter. Eigenverlag Forschungsinstitut für Umweltinformatik, Linz, 159 pp. (in German).

Reiprich A. (1960): Motýle Slovenska: Oblast' Slovenského raja. [Butterflies of Slovakia: The area of the Slovak Paradise]. Vydavatelstvo Slovenskej Akadémie Vied, Bratislava, 556 pp. (in Slovak).

Reiprich A. \& Okáli I. (1989): Dodatky k Prodromu Lepidopter Slovenska. 3. zväzok. [Additions to the prodrome Lepidoptera of Slovakia. Third volume]. Vydavatel'stvo SAV, Bratislava, 144 pp. (in Slovak, Russian and German summary).

Sielezniew M. \& Dziekańska I. (2010): Motyle dzienne. Fauna Polski. MULTICO Oficyna Wydawnicza, Warszawa, 336 pp. (in Polish).

Skala H. (1912): Die Lepidopterenfauna Mahrens I. - Verh. naturforsch. Ver. Brünn 50: 63-241. (in German).

- (1936): Zur Lepidopterenfauna Mährens und Schlesiens. - Acta Musei Moraviae 30(Suppl.): 1-197. (in German).

Spitzer K. (1963): Rozšíření Pararge hiera F. na Moravě (Lep., Satyridae). [Distribution of Pararge hiera F. (Lep., Satyridae) in Moravia]. - Časopis Československé Společnosti Entomologické 60: 263. (in Czech, German summary).

Spitzer L. (2008): Okáč stínovaný (Lasiommata petropolitana): pátrání na posledních známých lokalitách v ČR Zpráva z realizace projektu ČSOP číslo 01010508. 8 pp. [Ms. depon in Muzeum regionu Valašsko, Vsetín].

Stiova L. (1975): Výskyt denních motýlů v Moravskoslezských Beskydech a Vsetínských vrších. [The occurrence of butterflies in the Moravian-Silesian Beskids and the Vsetínské hills]. - Entomologický Zpravo-daj (Ostrava) 5(2,3): 1-24, 1-8. (in Czech).

Štika J. (2007): Valaši a Valašsko. O původu Valachů, valašské kolonizaci, vzniku a historii moravského Valašska a také o karpatských salaších. Valašské muzeum v př́rodě, Rožnov pod Radhoštěm, 237 pp. (in Czech).

Šumpich J. (2007): Významné nálezy motýlů (Lepidoptera) v Národním parku Podyjí. [Significant records of Lepidoptera in Podyjí National Park]. - Thayensia 7: 249-286. (in Czech, English summary).

Švestka M. \& Vítek P. (1988): Denní motýli (Lepidoptera, Rhopalocera a Zygaenidae) Znojemska. - Acta Scientiarum Naturalium Musei Moraviae Occidentalis, Třebíč 16: 25-53. (in Czech, English summary).

Tkáčiková J. \& Spitzer L. (2011): K zalesňování na Valašsku. - Valašsko - vlastivědná revue, Muzeum region Valašsko, Vsetín 2011/1: 30-34. (in Czech).

Tkáčiková J., Husák J. \& Spitzer L. (2013): Valašské louky a pastviny - dědictví našich předků. Muzeum regionu Valašsko, p.o. a Musejní společnost ve Valašském Meziř́íćí, Vsetín, 144 pp. (in Czech). 
Uřičář J., Jongepierová I. \& Vondřejc T.E. (2016): Zásady péče o významné druhy motýlů Bílých Karpat. ZO ČSOP Bílé Karpaty, Veselí nad Moravou, 56 pp.

Van Swaay C.A.M. \& Warren M.S. (1999): Red Data book of European butterflies (Rhopalocera). Nature and Environment, No. 99. Council of Europe Publishing, Strasbourg.

Wilson R.J., Bennie J., Lawson C.R., Pearson D., Ortuzar-Ugarte G. \& Gutierrez D. (2015): Population turnover, habitat use and microclimate at the contracting range margin of a butterfly. - Journal of Insect Conservation 19: 205-216.

Authors’ addresses: Lukáš Spitzer, Muzeum regionu Valašsko, Horní náměstí 2, CZ-755 01 Vsetín, Česká republika.

E-mail: spitzer.lukas@gmail.com

Jiří Ben eš, Institute of Entomology, Czech Academy of Sciences, Branišovská 31, CZ-370 05 České Budějovice, Česká republika.

E-mail: benesjir@seznam.cz

Martin Konvička, Faculty of Science, University South Bohemia, Branišovská 31, CZ-370 05 České Budějovice, Česká republika.

E-mail: konva@entu.cas.cz 